\title{
Training Using Wrist Forearm Modification Tool
}

\author{
Gustama Setiyadi, Tri Irianto, and Ma'ruful Kahri \\ Faculty of Teacher Training and Education \\ Lambung Mangkurat University \\ Indonesia \\ gustamasetiyadi@yahoo.co.id
}

\begin{abstract}
The javelin throw requires an efficient release angle. The angle is at $30{ }^{\circ}$ to $36^{\circ}$. Observations made on the ground in novice athletes are used as a single sample because athletes have difficulty directing the javelin to get the correct throw angle. Athletes that perform javelin with reduced ability to release techniques result in the athlete's inhibition to get maximum throw performance. A stiff wrist causes this. Stiffness in the wrist is one factor that causes inadequate throwing performance. The reason is that a javelin that is not at an angle of $30^{\circ}$ to $36^{\circ}$ will find it difficult to reach the maximum distance. Thus, the problem of the ability of the javelin release technique is of concern for research. In this situation, the researchers presented a device called the wrist to practice the simulation of the javelin release technique. So, with training using a wrist device, problems with stiffness when removing the javelin can be overcome appropriately.
\end{abstract}

Keywords: effect of exercise, wrist forearm, javelin release technique

\section{INTRODUCTION}

One of the main factors influencing the yield of the javelin is the angle of release of the javelin. The efficient javelin angle was previously written by reference [1] which states that "the optimal angle of the body's longitudinal tilt (vertically forming), and the angle of release is between $30^{\circ}$ to $36^{\circ}$, the angle between the shoulder axis and the longitudinal axis around $90^{\circ}$. Reference [2] says that as many as $70 \%$ of athletes are trained and produced a throw as fast as 0.1 seconds at the time of release. Through this opinion, it can be concluded that the javelin will be at the right momentum when it is at the angle of the escape vector.

The problem in this study occurs when the researchers observe the ability of a sample to get a bad throw. It is because the javelin release experiences an inconsistent release angle, which is detrimental to the throw.

The effort to overcome the error of releasing technique is by giving simulation exercises. Reference [3] states that "simulation is a replication or visualization of the behavior of a system." The training to release a javelin using a wrist forearm device is the answer to the difficulties faced by athletes. Reference [4] says that "The intended target is specific to certain muscle groups, specific to a series of movement patterns, specialization of predominant energy systems." Wrist training is a reasonable reason to use the wrist forearm as a simulation tool to release the javelin. This is considered appropriate because the ability to release the javelin can specifically be associated with wrist training using a wrist forearm device. Reference [5] states that "An interesting finding in this study is that wrist speed is close to zero at the time of release. It could be because the tendons between the wrist and fingers simultaneously control the release of objects, which will be the angle of the object.

\section{METHOD}

This study employed the SSR approach (Single Research Subject). It is done because the sample in this study is casuistic and cannot be generalized. The research sample javelin thrower was taken from the Bekantan's Athletic Club.

This study used 2 (two procedures, where the first procedure is to determine the initial test. Determining the initial test in this study is a sample that would be thrown 6 (six) times, then measure the results of the toss and see the angle of releasing the javelin with Kinovea application. In the intervention procedure, the athlete performs a simulation of releasing the javelin using the forearm wrist using maximum performance. The results obtained are 20, so the first treatment is $80 \%$ of the maximum performance test. The length of time to gather information to conclude is to do six tests along with angular analysis using the Kinovea application practicing for 18 meetings 6 times to do the test.

\section{RESUlTS AND DISCUSSION}

Data obtained from the first week to the sixth week, there were 3 (three) observations obtained. The first observation is measuring the results of the javelin throw with a meter, the second observation is the speed of the arm in releasing the javelin, and the third is the javelin release angle, which is supported by the Kinovea application. Based on our observations, we get the following results:

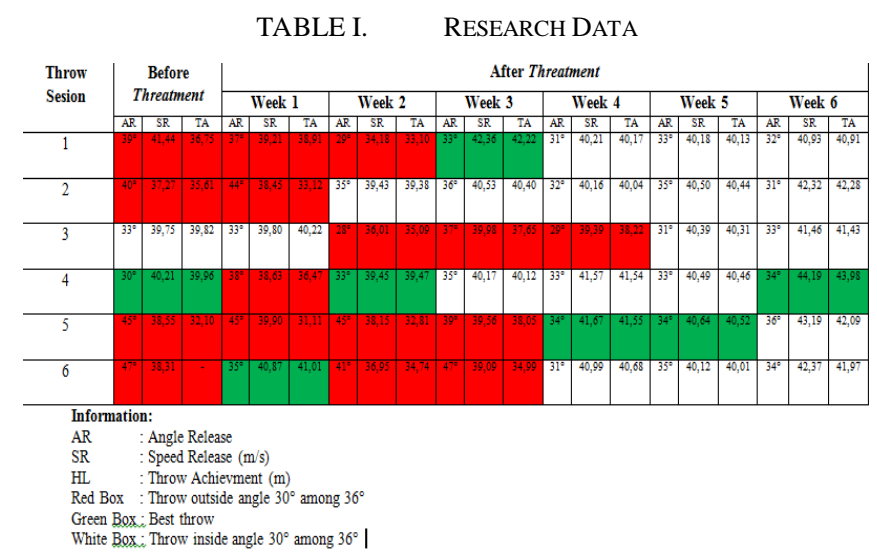

\section{A. Before Being Given an Intervention}

Based on the table of 6 (six) throws there are only 2 (two) throws at an angle of $30^{\circ}$ to $36^{\circ}$, namely the third throw at an angle of $33^{\circ}$ with the speed of releasing the javelin $39.75 \mathrm{~m} / \mathrm{s}$ to get the result of a throw of 39.82 meters and the fourth toss at an angle of $30^{\circ}$ with the speed of releasing the javelin 40.21 $\mathrm{m} / \mathrm{s}$ was obtained as far as 39.96 meters. The remaining 4 (four) inefficient throws are the first throw at an angle of $39^{\circ}$ with the speed of releasing the javelin $41.44 \mathrm{~m} / \mathrm{s}$ producing a 
of $32^{\circ}$ with a javelin release speed of $40.93 \mathrm{~m} / \mathrm{s}$ produces a throw as far as $40.91 \mathrm{~m}$, the second of the javelin at an angle of $31^{\circ}$ with a javelin release speed of $42.32 \mathrm{~m} / \mathrm{s}$ produces a throw of $42.28 \mathrm{~m}$. The third throw of the javelin at an angle of $33^{\circ}$ with the speed of releasing the javelin $41.46 \mathrm{~m} / \mathrm{s}$ produces a throw as far as $41.43 \mathrm{~m}$. The fourth javelin throw at an angle of $34^{\circ}$ with a javelin release speed of $44.19 \mathrm{~m} / \mathrm{s}$ produces a throw of $43.98 \mathrm{~m}$. The fifth throw of the javelin at an angle of $36^{\circ}$ with the speed of the arm releasing the javelin $43.19 \mathrm{~m} / \mathrm{s}$ produces a throw as far as $42.09 \mathrm{~m}$, and the sixth of the javelin is at an angle of $34^{\circ}$ with the speed of releasing the javelin $42.37 \mathrm{~m} / \mathrm{s}$ resulting in a throw of $41.97 \mathrm{~m}$.

\section{Throwing Observation Results}

Based on data obtained from the first week to the sixth week, it was found that there was a very significant change in the javelin angle. In the javelin angle graph that has been presented, it is seen that there is a difference in the consistency of the angles from the first, second and third angle of the throw is still unstable, while the fourth and sixth week of the corner of the javelin jaw release at an angle of $30^{\circ}$ to $36^{\circ}$.

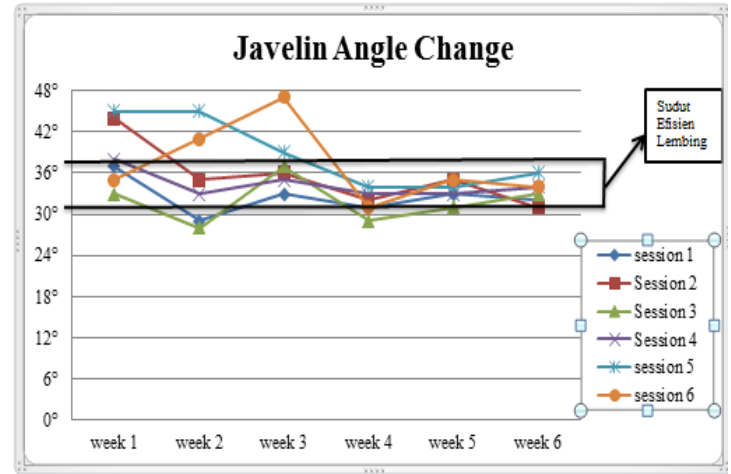

Fig. 1. Javelin Angle Change

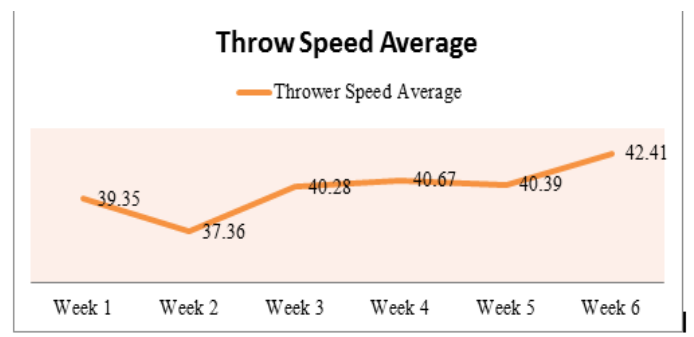

Fig. 2. Throw Speed Average

In the graph above, there is a change in speed. In the first week, the average speed was $39.35 \mathrm{~m} / \mathrm{s}$. In the second week, the average speed was $37.36 \mathrm{~m} / \mathrm{s}$. In the third week, the average speed was at $40.28 \mathrm{~m} / \mathrm{s}$. In the fourth week, the average speed was $40.67 \mathrm{~m} / \mathrm{s}$. In the fifth week, the average speed is $40.39 \mathrm{~m} / \mathrm{s}$, and in the sixth week, the average speed reaches $43.41 \mathrm{~m} / \mathrm{s}$.

\section{Throw Results}

Based on the javelin angle obtained is supported by the javelin velocity, then it affects the outcome of the toss. In the first week occurs in the sixth throw of $41.01 \mathrm{~m}$. Then in the second week, the best throw occurs in the fourth toss, 39.47 $\mathrm{m}$. In the third week, the best throw occurs at the first throw, which is $42.22 \mathrm{~m}$. In the fourth week, the best throw occurs at the fifth throw, which is $41.55 \mathrm{~m}$; in the fifth week, the best throw occurs at the fifth throw, which is $40.52 \mathrm{~m}$. In the sixth

6) The observations in the sixth week
On the 6th week, all the tosses taken are entirely stable at an angle of $30^{\circ}$ to $36^{\circ}$. The first throw of the javelin at an angle 
week, the best throw occurs at the fourth throw, which is 43.98

m.

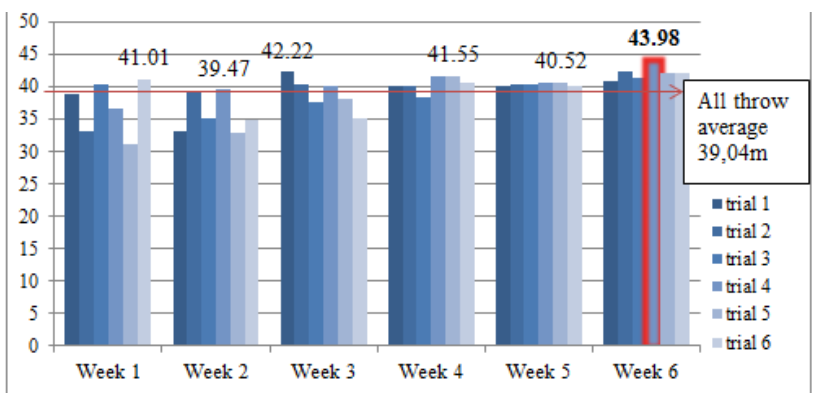

Fig. 3. Throw Result

TABLE II. The Most EFFective JaVELIN RELEASE ANGLE

\begin{tabular}{|c|c|c|}
\hline Angle & Throw (Meter) & Throw average (Meter) \\
\hline \multirow{4}{*}{$31^{\circ}$} & 40.17 & \multirow{4}{*}{40,86} \\
\hline & 40.68 & \\
\hline & 40.31 & \\
\hline & 42.28 & \\
\hline \multirow[t]{2}{*}{$32^{\circ}$} & 40.04 & \multirow[t]{2}{*}{40,48} \\
\hline & 40.91 & \\
\hline \multirow{7}{*}{$33^{\circ}$} & 40.22 & \multirow{7}{*}{40,78} \\
\hline & 39.47 & \\
\hline & 42.22 & \\
\hline & 41.54 & \\
\hline & 40.13 & \\
\hline & 40.46 & \\
\hline & 41.43 & \\
\hline \multirow{4}{*}{$34^{\circ}$} & 41.55 & \multirow{4}{*}{$\begin{array}{c}\text { Best Angle Throw } \\
42,00\end{array}$} \\
\hline & 40.52 & \\
\hline & 43.98 & \\
\hline & 41.97 & \\
\hline \multirow{5}{*}{$35^{\circ}$} & 41.01 & \multirow{5}{*}{40,2} \\
\hline & 39.38 & \\
\hline & 40.12 & \\
\hline & 40.44 & \\
\hline & 40.01 & \\
\hline \multirow[t]{2}{*}{$36^{\circ}$} & 40.4 & \multirow[t]{2}{*}{41,25} \\
\hline & 42.09 & \\
\hline
\end{tabular}

Based on the table, the most effective javelin angle is $34^{\circ}$. The reason for the researchers is because from that angle, the results of the throw appear to have the farthest average of 42.00 meters.

\section{CONCLUSION}

Based on research that has been done, it has been proven that the training of javelin throwing simulation using a wrist forearm can have an impact on the consistency of the ability to release the javelin at an angle of $30^{\circ}$ to $36^{\circ}$

\section{REFERENCES}

[1] Hans Joacim Hanzel, Biomechanics of Javelin Throwing, IAAF, 1986

[2] C. Morris and R. Bartlett, Sports Medicine, vol. 21, 1996.

[3] S. S. Udin, Penerapan Simulasi Animasi, Bina Sarana, 2005.

[4] H.B. Bafirman "Kontribusi Fisiologi Olahraga Mengatasi Resiko Menuju Prestasi Optimal," Jurnal Media Ilmu Keolahragaan Indonesia, vol. 3 no. 1, 2013.

[5] Q. Zhu, J. Dapena, and G. P. Bingham, "Learning to throw to maximum distances: Do changes in release angle and speed reflect affordances for throwing?," Human Movement Science, vol. 28 no. 6, 2009, pp. 708-725. 